\title{
THE MECHANISM OF GLUCOSE EXCRETION BY THE KIDNEY IN DIABETIC DOGS
}

\author{
By PAUL GOVAERTS and PAUL MULLER \\ (From the Department of Experimental Medicine, University of Brussels, Brussels, Belgium)
}

(Received for publication August 22, 1938)

Kidney function has long been explained by two rival concepts, the secretion theory and the filtration-reabsorption theory, both being based upon inferences and indirect arguments rather than upon direct observations. Since the splendid work of Richards and his collaborators (1), the study of renal function is no longer a matter of theoretical discussion but one of exact measurements and analysis. As a result of these investigations and those of Rehberg (2), Marshall (3), and Homer Smith (4), it has been shown that the formation of the urine results from glomerular filtration, tubular reabsorption, and from some secretory activities. The relative importance of these processes depends on the particular species of animals under consideration.

In amphibians, the behavior of the glucose in the kidney is known in the minutest details. Direct observations and analysis of fluids collected from different levels of the nephrons in the frog and Necturus have shown that the concentration of glucose is the same in the glomerular fluid as in the plasma, and that glucose is reabsorbed by the proximal portion of the tubules. When a full dose of phlorizin is injected into a frog, the tubular cells fail to reabsorb the glucose and the latter is thus found in the bladder urine. Aglomerular fishes do not excrete glucose when the plasma glucose is raised to a very high level, nor after administration of phlorizin. These observations can be interpreted as follows: the glucose is not secreted, but reaches the nephron only by the process of glomerular filtration and is reabsorbed by the tubules. The action of phlorizin consists in blocking the tubular reabsorption of glucose.

If these observations may be fully applied to mammals, all of the filtered glucose should appear in the bladder urine when reabsorption is wholly blocked by phlorizin. In order to verify this assumption, it is necessary to determine the volume of the glomerular filtrate accurately.
In 1926, Rehberg (2) suggested that the creatinine clearance may be used to measure the volume of the glomerular filtrate. According to Smith, Rehberg's inference is not correct for man, the anthropoid apes, and the birds, but is correct for the dog. So, for the dog, we can calculate the amount of filtered glucose by multiplying the creatinine clearance (filtration) by the concentration of the glucose in the arterial plasma, as it may be assumed that the concentration of glucose in the glomerular filtrate is the same as that in the arterial plasma. It is now easy to determine whether after the administration of phlorizin the total amount of filtered glucose is excreted. Poulsson (5) has proven the soundness of that concept experimentally. When a large dose of phlorizin is injected into a dog, the concentration index of glucose may equal the concentration index of creatinine. This means that if the kidney excretes in one minute the creatinine present in 60 cc. of plasma, it excretes during the same period the glucose present in $60 \mathrm{cc}$. of plasma. These findings have been confirmed by Jolliffe, Shannon, and Smith (6), by White and Monaghan (7) and by Govaerts and Cambier (8). Therefore, one is led to infer that in the dog as well as in the frog glucose enters the nephron only by glomerular filtration. If, under normal conditions, no glucose is found in the bladder urine, it is because this substance is completely reabsorbed by the tubules. When the concentration of glucose is raised in the plasma, it increases to the same extent in the glomerular filtrate. Thus, the amount of glucose presented to the reabsorbing cells reaches such a height that the reabsorption ceases to be complete. Fisher and Shannon (quoted by Smith (4) page 112) have studied the excretion of glucose by the kidney of a normal dog. The glucose in the arterial plasma was maintained at a very high level by the constant intravenous infusion of a glucose-saline solution. The quantity of glucose reabsorbed by the tubules remained 
constant although the plasma level was raised from 300 to $2400 \mathrm{mgm}$. per cent. "It would appear that the glucose 'threshold' has its origin in the fact that the tubules can reabsorb glucose up to some constant, maximal quantity per unit time; if presented in excess of this quantity, the remainder is allowed to escape in the urine." ( $H$. Smith.)

These observations give a very striking definition of the mechanism of glucosuria caused by intravenous infusions of glucose in the normal dog. The purpose of the present work is to determine whether the mechanism of glucose excretion in diabetic dogs is identical with that which has been found in the normal animal.

We have studied three dogs in which a diabetic condition had been induced by total pancreatectomy. The bladder was permanently fistulated by an ebonite cannula. These animals were kept in good condition for several months by daily injections of insulin. The total quantity of filtered glucose per minute may be computed by multiplying the creatinine clearance (filtration) by the concentration of glucose in the arterial plasma. The difference between this quantity and the amount of glucose excreted per minute gives the total amount of glucose reabsorbed by the tubules. Thus one may calculate the amount of glucose reabsorbed by the tubules from each cubic centimeter of glomerular filtrate, that is, from each cubic centimeter of a solution of glucose having the same concentration as the arterial plasma. We call this figure the "threshold," as, when expressed in grams per cent, it indicates which portion of the plasma glucose is not excreted under the conditions of the experiment.

\section{METHODS}

The experiments were performed without anesthesia, as they did not include any painful procedure. Two to 3 grams of creatinine dissolved in $200 \mathrm{cc}$. of tepid water were administered by stomach tube. Half an hour later, $500 \mathrm{cc}$. of water were given in the same way. When a marked diuresis was present, the urine was collected during a 2 to 5-minute period and at the same time a blood sample was drawn by femoral puncture. Glucose and creatinine were determined in the urine and in the arterial plasma.

The experiments on Dog I were all carried out when the animal had been fasting overnight, the purpose of this procedure being to keep the plasma glucose as constant as possible during the experiments. The blood glucose of Dogs II and III was raised in most of the experiments by intravenous infusions of glucose-saline or by introducing a glucose solution into the stomach.

Blood. The blood was drawn by femoral puncture, collected in a tube containing some sodium fluoride and immediately centrifuged. A $1 / 10$ dilution was made by adding to $2 \mathrm{cc}$. of plasma $16 \mathrm{cc}$. of distilled water, $1 \mathrm{cc}$. of $2 / 3 \mathrm{~N}$ sulfuric acid and $1 \mathrm{cc}$. of 10 per cent sodium tungstate solution, and filtering.

Urine. The method of West, Scharles, and Peterson (9) was used for the urinalyses, in order to avoid any decrease in reducing power. To $2 \mathrm{cc}$. of urine, $2 \mathrm{cc}$. of a 10 per cent solution of ferric sulfate were added, followed by $16 \mathrm{cc}$. of water. Two to 3 grams of powdered barium carbonate were then added to the solution. The mixture was thoroughly shaken and filtered. To the filtrate, a few milligrams of anhydrous sodium sulfate were added in order to precipitate the small amount of barium bicarbonate present. The precipitate was removed by centrifugation. This procedure yields urine dilutions absolutely colorless and without any turbidity.

Glucose. For Dog I, the colorimetric method of Benedict (10) was employed. Two cc. of tungstic filtrate of plasma and $2 \mathrm{cc}$. of diluted urine were used for the determinations. The urine, handled as described above, was diluted to such an extent that its final glucose concentration was nearly the same as that of the plasma filtrate. It was then possible to make the colorimetric readings for both filtrates against the color developed by the same glucose standard.

For Dogs II and III, the glucose analyses were made following the method of Shaffer and Somogyi (11). We allowed $2 \mathrm{cc}$. of filtrates of blood and urine to react with 2 cc. of copper solution number 50 , containing 3 grams of KI per liter. The agreement between duplicates was very satisfactory.

Creatinine. Creatinine was determined by the method of Folin and $\mathrm{Wu}(12)$. The analyses were performed upon tungstic filtrates of plasma and upon urine dilutions adjusted to allow colorimetric readings against the standard used for the blood filtrate. A Burker compensating colorimeter was used, supplied with a monochromatic filter. The readings were made with a stratum thickness of $20 \mathrm{~mm}$. and the 353 light filter. For the wavelengths transmitted by that light filter, the results conform with the Beer Lambert Law.

\section{RESULTS}

DOG I. Female, $12 \mathrm{kgm}$.

Pancreatectomy Dec. 30, 1937 . Vesical fistula Jan. 19, 1938.

Ten experiments were done during a period of two months. The hyperglycemia being spontaneous, the range of plasma glucose extended only from $268 \mathrm{mgm}$. per cent to $367 \mathrm{mgm}$. per cent. 
The results concerning this dog may be found in Table I and Figure 1.

TABLE I

Data on Dog I

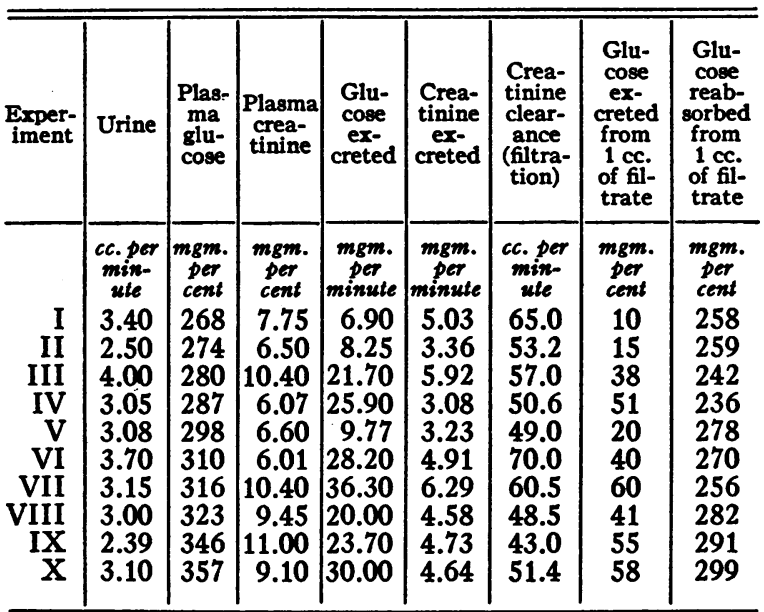

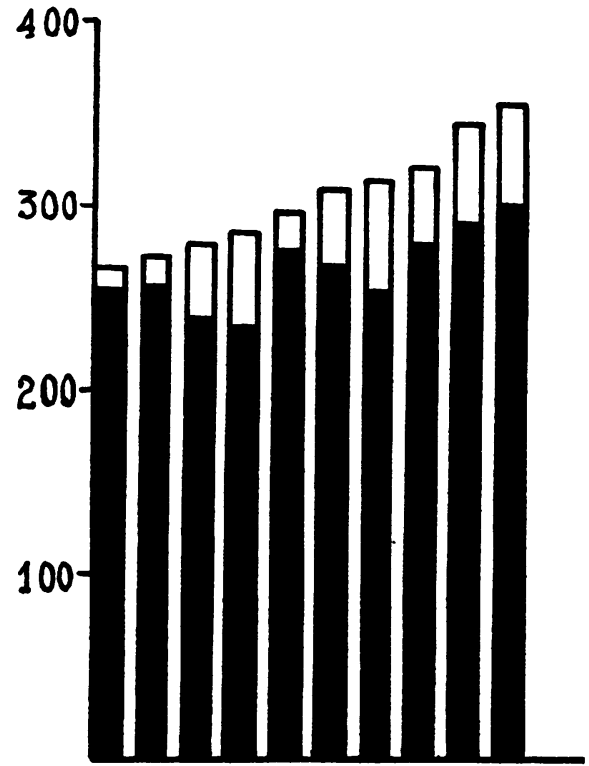

Fig. 1. Data on Dog I

Each column corresponds to a single experiment. Total height of the columns: arterial plasma glucose (mgm. per cent). Black: amount of glucose reabsorbed from each cc. of glomerular filtrate (mgm. per cent).

In these experiments, while the plasma glucose varied from 268 to $367 \mathrm{mgm}$. per cent, the quantity of glucose which was reabsorbed from $1 \mathrm{cc}$. of glomerular filtrate varied from 236 to 299 mgm. per cent. This indicates that in this range of moderate hyperglycemia, the amount of glu- cose reabsorbed by the tubules increases when the blood sugar level rises.

DOG II. Female, $14 \mathrm{kgm}$.

Pancreatectomy and vesical fistula Sept. 14, 1937.

Eight experiments were performed on this animal during a period of six weeks. The results may be found in Table II and Figure 2.

TABLE II

Data on Dog II

\begin{tabular}{|c|c|c|c|c|c|c|c|c|}
\hline $\begin{array}{l}\text { Exper- } \\
\text { iment }\end{array}$ & Urine & $\begin{array}{c}\text { Plas- } \\
\text { ma } \\
\text { glu- } \\
\text { cose }\end{array}$ & $\begin{array}{c}\text { Plasma } \\
\text { crea- } \\
\text { tinine }\end{array}$ & $\begin{array}{l}\text { Glu- } \\
\text { cose } \\
\text { ex- } \\
\text { creted }\end{array}$ & $\begin{array}{l}\text { Crea- } \\
\text { tinine } \\
\text { ex- } \\
\text { creted }\end{array}$ & $\begin{array}{l}\text { Crea- } \\
\text { tinine } \\
\text { clear- } \\
\text { ance } \\
\text { (filtra- } \\
\text { tion) }\end{array}$ & $\begin{array}{l}\text { Glu- } \\
\text { cose } \\
\text { ex- } \\
\text { creted } \\
\text { from } \\
1 \mathrm{cc} . \\
\text { of fil- } \\
\text { trate }\end{array}$ & $\begin{array}{l}\text { Glu- } \\
\text { cose } \\
\text { reab- } \\
\text { sorbed } \\
\text { from } \\
1 \mathrm{cc} . \\
\text { of fil- } \\
\text { trate }\end{array}$ \\
\hline & $\begin{array}{c}c c . \text { per } \\
\text { min- } \\
\text { ute }\end{array}$ & $\underset{\substack{\operatorname{mgm} \\
\text { per } \\
\text { cent }}}{ }$ & $\underset{\substack{\text { per } \\
\text { cent }}}{\operatorname{mgm} .}$ & $\underset{\text { per }}{\operatorname{mgm}}$ & $\underset{\text { per }}{\operatorname{mgm}}$ & $\begin{array}{c}\text { cc. per } \\
\text { min- }\end{array}$ & $\underset{\text { per }}{\operatorname{mgm}}$ & $\underset{\text { per }}{\operatorname{mggm}}$ \\
\hline $\begin{array}{r}\text { I } \\
\text { II } \\
\text { III } \\
\text { IV } \\
\text { V } \\
\text { VI } \\
\text { VII } \\
\text { VIII }\end{array}$ & $\begin{array}{l}2.94 \\
4.04 \\
5.67 \\
3.30 \\
3.23 \\
4.60 \\
\mathbf{5 . 5 8} \\
\mathbf{5 . 9 1}\end{array}$ & $\begin{array}{l}286 \\
372 \\
467 \\
482 \\
514 \\
557 \\
570 \\
610\end{array}$ & $\begin{array}{r}5.73 \\
7.94 \\
10.48 \\
8.82 \\
9.70 \\
11.70 \\
6.54 \\
13.98\end{array}$ & \begin{tabular}{|r}
11.0 \\
34.5 \\
96.0 \\
91.5 \\
75.0 \\
103.0 \\
138.0 \\
135.0
\end{tabular} & \begin{tabular}{|l}
3.99 \\
5.82 \\
8.17 \\
6.46 \\
5.91 \\
7.16 \\
4.86 \\
8.65
\end{tabular} & $\begin{array}{l}69.5 \\
73.4 \\
78.0 \\
73.2 \\
61.0 \\
61.2 \\
74.4 \\
61.8\end{array}$ & $\begin{array}{r}16 \\
47 \\
123 \\
125 \\
123 \\
168 \\
185 \\
218\end{array}$ & $\begin{array}{l}270 \\
325 \\
344 \\
357 \\
391 \\
389 \\
385 \\
392\end{array}$ \\
\hline
\end{tabular}

Here, the blood sugar varied from 286 to 610 mgm. per cent. The amount of glucose which the tubules reabsorbed from one cc. of glomerular filtrate at first rises with increasing glycemia, but when the blood sugar exceeds $500 \mathrm{mgm}$. per cent the threshold remains practically constant (between 385 and $392 \mathrm{mgm}$. per cent).

DOG III. Female, $13 \mathrm{kgm}$.

Pancreatectomy and vesical fistula. Feb. 22, 1938.

Twenty-two experiments were performed during a period of four months. The blood sugar concentration was 325 to $950 \mathrm{mgm}$. per cent. In Experiments 1 to 4 , the animals were fasting. In the other experiments the blood sugar was raised by an intravenous infusion of 100 to 200 cc. of 20 per cent glucose in saline. The collection of blood and urine was done from 2 to 5 minutes after the end of the infusion.

The results of these experiments may be found in Table III and Figure 3.

The range of blood sugar extends from 325 $\mathrm{mgm}$. to $957 \mathrm{mgm}$. per cent. The amount of glucose reabsorbed from $1 \mathrm{cc}$. of glomerular fil- 


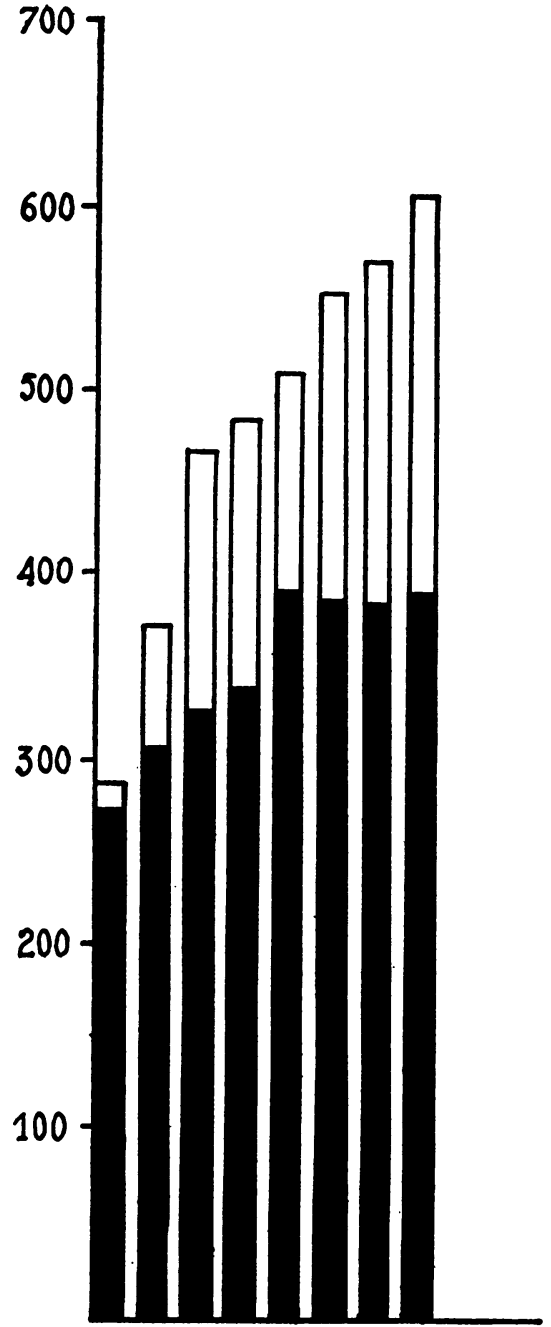

Fig. 2. Data on Dog II

Each column corresponds to a single experiment. Total height of the columns: arterial plasma glucose (mgm. per cent). Black: amount of glucose reabsorbed from each cc. of glomerular filtrate (mgm. per cent).

trate fluctuates between 287 and 394 mgm. per cent, with a mean value of $347 \mathrm{mgm}$. per cent.

\section{COMMENT}

We may outline the results of our experiments in the following way. When the concentration of glucose increases in the plasma, it rises to the same extent in the glomerular filtrate. At a certain moment, the reabsorptive power of the tubular cells cannot keep pace with the amount of glucose which is presented, and some of the glucose escapes into the urine. If the quantity presented
TABLE III

Data on Dog III

\begin{tabular}{|c|c|c|c|c|c|c|c|c|}
\hline $\begin{array}{l}\text { Exper- } \\
\text { iment }\end{array}$ & Urine & $\begin{array}{c}\text { Plas- } \\
\text { ma } \\
\text { glu- } \\
\text { cose }\end{array}$ & $\begin{array}{c}\text { Plasma } \\
\text { crea- } \\
\text { tinine }\end{array}$ & $\begin{array}{c}\text { Glu- } \\
\text { cose } \\
\text { ex- } \\
\text { creted }\end{array}$ & $\begin{array}{c}\text { Crea- } \\
\text { tinine } \\
\text { ex- } \\
\text { creted }\end{array}$ & $\begin{array}{l}\text { Crea- } \\
\text { tinine } \\
\text { clear- } \\
\text { ance } \\
\text { (filtra- } \\
\text { tion) }\end{array}$ & $\begin{array}{c}\text { Glu- } \\
\text { cose } \\
\text { ex- } \\
\text { creted } \\
\text { from } \\
1 \mathrm{cc}- \\
\text { of fil- } \\
\text { trate }\end{array}$ & $\begin{array}{c}\text { Glu- } \\
\text { cose } \\
\text { reab- } \\
\text { sorbed } \\
\text { from } \\
1 \mathrm{cc}- \\
\text { of fil } \\
\text { trate }\end{array}$ \\
\hline & $\begin{array}{c}\text { cc.per } \\
\text { min- } \\
\text { ute }\end{array}$ & $\begin{array}{c}\text { mgm. } \\
\text { per } \\
\text { cent }\end{array}$ & $\begin{array}{c}\mathrm{mgm} . \\
\text { per } \\
\text { cent }\end{array}$ & 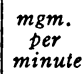 & $\begin{array}{c}\text { mgm. } \\
\text { per } \\
\text { minute }\end{array}$ & $\begin{array}{c}c c . \text { per } \\
\text { min- } \\
\text { ute }\end{array}$ & $\begin{array}{c}\text { mgm. } \\
\text { per } \\
\text { cent }\end{array}$ & $\begin{array}{c}\text { mgm. } \\
\text { per } \\
\text { cent }\end{array}$ \\
\hline I & 4.30 & 325 & 4.94 & 29.4 & 4.59 & 93.0 & 32 & 293 \\
\hline II & 0.45 & 349 & 17.80 & 13.9 & 13.23 & & & 330 \\
\hline III & 3.25 & 352 & 5.33 & 33.8 & 4. & & & 315 \\
\hline IV & & 360 & & 34.0 & & & & 318 \\
\hline V & 0.45 & 415 & 18.90 & 36.4 & 7. & & & 326 \\
\hline VI & & 421 & 15.2 & 63.0 & 13.77 & & & \\
\hline VII & & 458 & & & & & & 357 \\
\hline VIII & 1.72 & 469 & 19.65 & 100.5 & 13.36 & & & 319 \\
\hline IX & & 521 & & 133 & 13 & & & \\
\hline & & 524 & & & & & & \\
\hline XI & 3.00 & 534 & 21. & 161.0 & 15. & 75 & & 32 \\
\hline XII & & & & & & & & \\
\hline XIII & & 537 & & & & & & \\
\hline XIV & 2 & 551 & 13. & 140.0 & 8. & 67 & & 34 \\
\hline & & & & & & & & \\
\hline & & 595 & 20. & 16 & 15. & & & \\
\hline $\mathrm{X}$ & & 597 & 7. & 18 & & & & \\
\hline & & 60 & & & & & & \\
\hline XI & & 627 & 16. & 167 & 11. & & & 39 \\
\hline & & 778 & & 333.0 & & & & \\
\hline XXI & & 828 & 8. & 360 & & & & 308 \\
\hline XXII & 7.40 & 957 & 9.72 & 410.0 & 6.49 & 65.8 & 623 & 334 \\
\hline
\end{tabular}

increases further, the reabsorption increases also, but nevertheless it is more and more overburdened. If the plasma glucose continues rising, the reabsorptive capacity of the tubular cells becomes completely saturated, and the quantity of reabsorbed glucose remains practically constant at this maximal value for any further increase of glycemia. It is very tempting to compare the renal function under those circumstances with that of the phlorizinized dog. In the latter, the reabsorption of glucose is completely blocked by phlorizin and consequently the total amount of filtered glucose is found in the bladder urine. In the diabetic dog, a constant part of the filtered glucose saturates the reabsorptive power of the tubular cells and the remainder is completely excreted as it should be in a phlorizinized dog. The blocking of reabsorption which in the phlorizinized dog is produced by a drug is caused in the diabetic animal by the glucose itself.

These conclusions are based on the mean values of our results. When comparing single experiments, one finds that the "threshold" fluctuates appreciably. The meaning of these fluctuations 


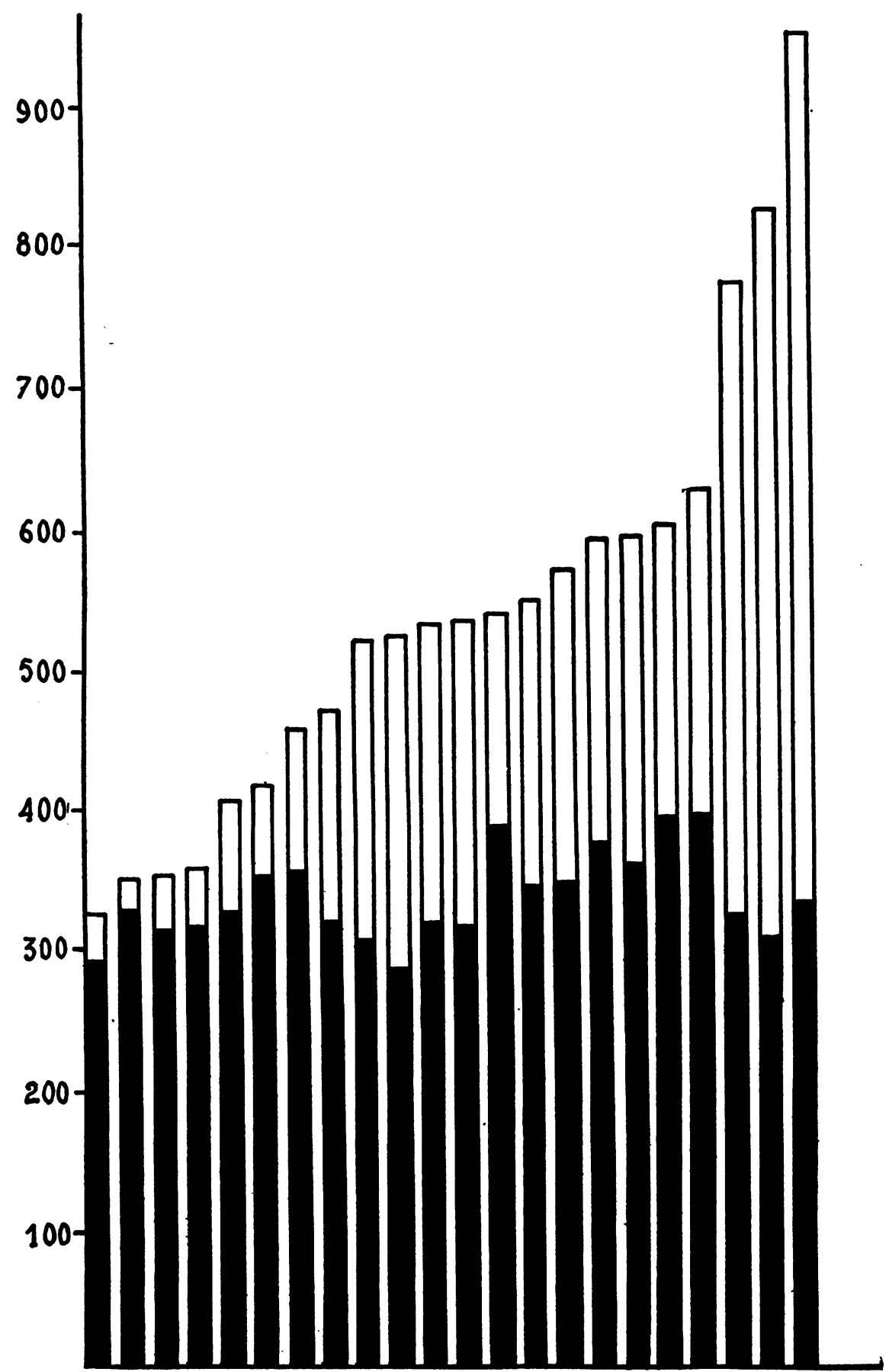

Fig. 3. Data on Dog III

Each column corresponds to a single experiment. Total height of the columns: arterial plasma glucose (mgm. per cent). Black: amount of glucose reabsorbed from each cc. of glomerular filtrate (mgm. per cent). 
is difficult to interpret for the moment. They may be owing in great part to the unavoidable and cumulative errors in collecting urine and blood, and in the chemical determinations. Furthermore, it is very likely that the reabsorptive power of the tubular cells may be influenced by several factors, for instance variations in the number of functionating glomeruli or modifications in the volume of fluid filtered by single glomeruli, changing the rate of flow through the tubules. Other factors may be of importance, such as hormonal influences, but they are still to be determined.

Our observations prove that the mechanism of glucose elimination in diabetic dogs is the same as that found by Fisher and Shannon in normal dogs when a high level of glycemia was maintained by a continuous injection of glucose-saline. It is worth noticing that the renal threshold in our diabetic dogs did not undergo any appreciable change during a period of observation which lasted several months. Moreover, the threshold, defined by the maximal quantity of glucose reabsorbed by the tubular cells from $1 \mathrm{cc}$. of glomerular filtrate is not the same for each dog, as it is about $390 \mathrm{mgm}$. per cent for Dog II and 347 mgm. per cent for Dog III.

The threshold is variable in the range of moderate hyperglycemia ; it rises when the blood sugar increases. When the level of hyperglycemia is high, the threshold stays at a maximal value which is not the same in different individuals. These facts explain why the renal threshold presents itself both as a permanent individual character and as a rather elusive value, varying appreciably when the level of blood sugar is only moderately raised.

\section{SUMMARY}

1. In dogs made diabetic by pancreatectomy, the excretion of glucose and creatinine has been studied.

2. Considering the creatinine clearance as a measure of the glomerular filtration and the glucose concentration of the arterial plasma as equal to the concentration of this substance in the glomerular filtrate, one may calculate the quantity of glucose which the tubular cells reabsorb from $1 \mathrm{cc}$. of glomerular filtrate. This figure is called the "threshold." When the blood sugar concentration increases moderately, this threshold increases. With further elevation of the blood sugar, the threshold soon reaches a maximal value which remains constant for any higher level of glycemia.

3. In the diabetic dog, at high levels of hyperglycemia, a constant part of the filtered glucose saturates the reabsorptive power of the tubular cells and the remainder is completely excreted as in a phlorizinized dog.

4. These characteristics of the renal function did not change appreciably in the diabetic dogs during a period of observation which lasted several months.

\section{BIBLIOGRAPHY}

1. Richards, A. N., Methods and Results of Direct Investigations of the Function of the Kidney. Williams and Wilkins Co., Baltimore, 1929.

Richards, A. N., and Walker, A. M., Urine formation in the amphibian kidney. Am. J. M. Sc., 1935, 190, 727.

2. Rehberg, P. B., Studies on kidney function. The rate of filtration and reabsorption in the human kidney. Biochem. J., 1926, 20, 447.

3. Marshall, E. K., Jr., The comparative physiology of the kidney in relation to theories of renal secretion. Physiol. Rev., 1934, 14, 133.

4. Smith, H. W., The Physiology of the Kidney. Oxford University Press, New York, 1937.

5. Poulsson, L. T., On the mechanism of sugar elimination in phlorrhizin glycosuria. J. Physiol., 1930, 69, 411.

6. Jolliffe, N., Shannon, J. A., and Smith, H. W., The excretion of urine in the dog. III. The use of nonmetabolized sugars in the measurement of the glomerular filtrate. Am. J. Physiol., 1932, 100, 301.

7. White, H. L., and Monaghan B., A comparison of the clearances of various urinary constituents. Am. J. Physiol., 1933, 104, 412.

8. Govaerts, P., and Cambier P., Elimination comparée du glucose, de la créatinine et de l'urée sous l'influence de la phlorizine. Bull. Acad. roy. de-méd. de Belgique, 1934, 14, 226.

9. West, E. S., Scharles, F. H., and Peterson, V. L., The determination of true sugar in blood. J. Biol. Chem., 1929, 82, 137.

10. Benedict, S. R., Determination of sugar in blood. J. Biol. Chem., 1929, 83, 165.

11. Shaffer, P. A., and Somogyi, M., Copper iodometric reagents for sugar determinations. J. Biol. Chem., 1933, 100, 695.

12. Folin, $O$, and $W u, H ., A$ system of blood analysis. J. Biol. Chem., 1919, 38, 81. 